\title{
Future long-term care expenditure in Germany, Spain, Italy and the United Kingdom
}

\author{
ADELINA COMAS-HERRERA*, RAPHAEL WITTENBERG*, \\ JOAN COSTA-FONT $\dagger^{*}$, GRISTIANO GORI**, ALESSANDRA \\ DI MAIO**, CONCEPCIÓ PATXOT $†$, LINDA PICKARD*, \\ ALESSANDRO POZZI** and HEINZ ROTHGANG ${ }^{*} \dagger$
}

\begin{abstract}
This paper reports findings from a European Commission funded study of future long-term care expenditure in Germany, Italy, Spain and the United Kingdom, and presents projections of future long-term care expenditure in the four countries under a number of assumptions about the future. Macro-simulation (or cell-based) models were used to make comparable projections based on a set of common assumptions. A central base-case served as a point of comparison by which to explore the sensitivity of the models to alternative scenarios for the key determinants. The sensitivity of the models to variant assumptions about the future numbers of older people, the prevalence of functional dependency and informal care, patterns of long-term provision, and macroeconomic conditions are examined. It was found that, under the base-case, the proportion of gross domestic product spent on long-term care is projected to more than double between 2000 and $205^{\circ}$ in each country. The projected future demand for longterm care services for older people is sensitive to assumptions about the future number of older people, the prevalence of dependency and the availability of informal care, and projected expenditure is sensitive to assumptions about rises in the real unit-costs of services and the structure of the models. It is important, for planning purposes, to recognise the considerable uncertainty about future levels of long-term care expenditure.
\end{abstract}

$\boldsymbol{K E Y} \boldsymbol{W} \boldsymbol{W} \boldsymbol{D} \boldsymbol{S}$ - Long-term care expenditure, demand for long-term care, projections.

* Personal Social Services Research Unit, London School of Economics and Political Science, UK.

$\dagger$ Research Group on the Economics of Social Policy, Universitat de Barcelona, Spain.

** Istituto per la Ricerca Sociale, Milano, Italy.

$\dagger \dagger$ Centre for Social Policy Research, Bremen University, Germany. 


\section{Introduction}

Long-term care services are crucial to the welfare of many older people. Such care is usually taken to mean help with domestic tasks, such as shopping and preparing meals, and assistance with personal care tasks, such as dressing, bathing and nursing care. Most long-term care for older people in Europe is currently provided by informal carers, but it is also delivered by formal services, including residential care homes for older people, day care at day centres, and home-based care such as community nursing and home-help services. In most European countries, these services are largely funded from the public exchequer, at least for poorer people (Glendinning et al. 2004). As the very old population rises throughout Europe, the number of clients and expenditure on these services is expected to increase. In many countries, there are concerns about how much long-term care expenditure will need to rise to meet the needs of an increasing older population, mirroring the similar concerns about future expenditure on pensions and health care.

The European Commission 'Economic Policy Committee' (EPG) has investigated the impact of population ageing on future public expenditure on pensions, health and long-term care, and how it would affect the fiscal sustainability of public finances; it has produced projections of future expenditure on these services that will be updated in 2005 (Economic Policy Committee 200I, 2003). The key issues in making projections of future expenditure on long-term care are to consider what factors drive this expenditure and to investigate the sensitivity of the projections to changes in those factors.

This article reports the findings from the European Study of Long-Term Care Expenditure, which was partly funded by the European Commission. This has investigated the factors that are likely to affect future expenditure on long-term care services in Germany, Spain, Italy and the United Kingdom (UK). The paper describes the models used in each country and sets out the projections of future long-term care expenditure produced under a set of common assumptions. It then investigates the sensitivity of those projections to variant assumptions about future trends in life expectancy, trends in functional dependency, trends in the future availability of informal care and trends in the unit-costs of services. ${ }^{1}$ The project also investigated the sensitivity of the projections to other factors, such as trends in the structure of formal long-term care services and patterns of provision (see Pickard et al. 2003). 


\section{The long-term care systems of the four countries}

The systems of long-term care for older people differ substantially among the four countries, which has important consequences for the development and interpretation of national projections of long-term care expenditure. This section provides a context for the projections, by describing briefly the main characteristics of long-term care in the four countries (for more detailed accounts, see Comas-Herrera and Wittenberg 2003).

\section{Germany}

Germany has introduced a mandatory social insurance scheme for longterm care that covers virtually the entire population (Rothgang 2003; Schneider I999). About 9o per cent of the population are covered by a pay-as-you-go insurance scheme ('social insurance'). The rest of the population is covered by a funded, mandatory, private insurance scheme. The social insurance scheme has national eligibility criteria that, if met, entitle the individual to different types of services or cash benefits: three dependency levels determine the level of benefits. The scheme is financed through social insurance contributions paid by employees and employers. There is no means-test for the scheme's benefits, but there is means-tested social assistance to finance the costs of care that exceed the benefit payments. The definition of long-term care in Germany is somewhat narrower than in the other three countries, for to qualify for long-term care benefits, individuals must require help for more than go minutes a day over six months with at least two activities of daily living. People with lower levels of dependency are not covered by the long-term care insurance.

\section{Spain}

The Spanish system is highly decentralised and can be characterised as a 'system of regional long-term care services' (Costa-Font and Patxot 2003, 2005). There is great reliance on informal care but, as the rate of participation of women in the labour force has been increasing, it is expected that Spain will become increasingly reliant on formal care. Access to publicly-funded long-term care is based on an assessment of needs and resources, which varies by the autonomous region. Services are tightly rationed because of the low level of provision. Social care services tend to be regulated by the regional governments, are provided by both local authority and private-sector (mostly non-profit) providers, and they tend to be means-tested. Health-care services are provided free-of-charge by 
the National Health Service, which is also organised at the regional level. Long-term care in Spain is financed mainly through taxes and, to a lesser extent, co-payments and charges. The current policy debates are how to improve the integration of health and social care and how best to finance long-term care.

\section{Italy}

In Italy, public long-term care for older people has three main sources of assistance: community care, institutional care and cash allowances. Long-term care is delivered by public and private providers of health and personal social care. Health services provided by the National Health Service are free-of-charge, whereas social care is means-tested. National and local taxation are the main sources of finance. Notable features of the Italian system are generous cash-benefits that are not means-tested, which may explain Italy's strong reliance on private home-based care, much of which is purchased in the grey economy (Ungerson 2004). The level of provision of publicly-financed, community-based services is expected to increase. For a more detailed description of the Italian long-term care system, see Gori, Di Maio and Pozzi (2003).

\section{United Kingdom}

In the United Kingdom (UK), as in Italy and Spain, health services under the National Health Service (NHS) are 'free at the point of use', whereas social care services arranged by local authorities are subjected to means-tests. Primary Care NHS Trusts are responsible for arranging health-care services for their populations. Local authorities are responsible for assessing needs, setting eligibility criteria and arranging social services for their populations. Access to services is through an assessment of care needs. There is a strong emphasis on targeting the available services to the most dependent, and a growing emphasis on rehabilitation. Health services are funded mainly from central taxation, whereas social services are funded from central and local taxation and user-charges. Debate about how to fund long-term care continues. The means-test has been removed for nursing care and personal care in Scotland, but for nursing care only in the rest of the UK. For a more detailed description of the UK system, see Comas-Herrera, Wittenberg and Pickard (2004).

Table I illustrates the differences between the four systems. It shows the proportion of older dependent people in 2000 who: relied exclusively on informal care ('informal care only'), or used some form of paid-care while living in private households ('formal home-care'), or were living in institutions. It is important to interpret this table with caution as the 
T А в L E I. Estimated utilisation by older dependent people of three forms of long-term care in Germany, Spain, Italy and the UK in 2000

\begin{tabular}{lccc}
\hline & \multicolumn{3}{c}{ Percentage receiving } \\
\cline { 2 - 4 } & $\begin{array}{c}\text { Informal-care } \\
\text { only }\end{array}$ & $\begin{array}{c}\text { Formal } \\
\text { home-care }\end{array}$ & $\begin{array}{c}\text { Institutional } \\
\text { care }\end{array}$ \\
\hline Germany (two or more ADLs) & 46 & $2 \mathrm{I}$ & 33 \\
Spain (one or more ADLs) & 69 & I4 & I7 \\
Italy (one or more ADLs) & 37 & 40 & 23 \\
UK (two or more ADLs) & 32 & 36 & $3^{1}$ \\
\hline
\end{tabular}

Notes: The estimates are from model estimates. I. The UK figure excludes a relatively small number of people $(26,000)$ who receive neither formal nor informal care. For more details of the source data and the methods of estimation, see the text, Rothgang and Comas-Herrera (2003) and Pickard (2003a).

national definitions of dependency varied (for details see Rothgang and Comas-Herrera 2003), and what is understood for each type of care, in particular 'formal home-care', varies substantially. The interpretation of these figures is further discussed in Pickard (2003 $a$ : 215).

\section{The long-term care projection models}

\section{Overview of the models}

The aims, coverage and structure of the four models used in this study differ. As well as representing different long-term care systems, the models had different original purposes and origins. The UK model aimed to represent the whole long-term care sector for older people, to inform the debate about what should be funded by the state and what by individuals (Wittenberg et al. 1998, 2001; Comas-Herrera and Wittenberg 2003). The German model aimed to represent the German social insurance system for long-term care, to estimate the required size of future contributions (Rothgang 1997, 2002 $a, 2002 b$ ). The Italian model and, to some extent the Spanish model, were developed especially for this project, but limited data were available in these two countries, partly as the result of the substantial decentralisation of their long-term care systems. ${ }^{2}$

The reported models are cell-based or macro-simulation models with a common structure, and they produce three sets of estimates: of the future numbers of dependent older people (aged 65 or more years), of the volume of services that they will require, and of the expenditure that those services will require. The projections of the numbers of older people are by age, gender, dependency and, in some models, other characteristics. The measures of dependency were defined with reference to the ability to 
perform the activities of daily living (ADLs) and the instrumental activities of daily living (IADLs), but the exact measures differed by country (for details, see Rothgang and Comas-Herrera 2003). The second set of estimates covers the future numbers of dependent older people and the probabilities of receiving three types of services: informal care, formal services in their own homes, and institutional care. The third set of estimates calculates the expenditure required to pay for those services by applying unit or per capita costs.

All four national models cover a range of long-term care services and, as far as possible, both the public and the private sectors (in terms of provision and funding). They include informal care by family and friends, ${ }^{3}$ services provided to people who live in their own homes, and services provided to those living in institutions. Cash allowances have only been included when there is a specific choice between cash and services, as in the German system. The rationale was that, in Germany, the value of services on offer was higher than the cash allowance, and therefore people were unlikely to use their cash allowances to purchase formal care. In the UK and Italy, however, disability benefits are often used as payments for private care (and to meet public-sector charges), and are not alternatives to care. Their inclusion in total expenditure would therefore be double counting. It should be stressed that the models do not make forecasts, but rather projections on the basis of specific assumptions about the future. The approach involves simulating the impact on demand of specified hypothetical changes in the size and age structure of the population, in household composition, and in patterns of long-term care services (such as more support for informal carers). It does not forecast future policies or future patterns of care.

\section{The central assumptions and the base-case projections}

A common core set of assumptions (as summarised in Table 2) was used for the 'central' projections that enable comparisons of the likely impact of stipulated demographic and other pressures among the countries. They serve as the reference cases against which the effect of changes in the different assumptions can be investigated. Table 3 presents the central base-case projections for each country. It shows that Spain would have the greatest rise in the projected numbers of old and very old people between 2000 and 2050 under the central projection assumptions. In Spain, the projected number of people aged 85 or more years and over in 2050 would be three times the number in 2000, whereas in the UK, the same age group would increase 2.5 times, and in Germany and Italy the increases would be in-between. Table 3 also shows that the numbers of dependent 
T А в L E 2. The central base-case assumptions

\begin{tabular}{|c|c|}
\hline Factor & Assumptions \\
\hline \multirow[t]{3}{*}{$\begin{array}{l}\text { Numbers of older } \\
\text { people and their } \\
\text { characteristics }\end{array}$} & $\begin{array}{l}\text { Older population by age and gender changes in line with } \\
\text { Eurostat I999-based population projections. These are country- } \\
\text { specific, but are based on a common methodology. }\end{array}$ \\
\hline & $\begin{array}{l}\text { Prevalence rates of dependency by age and gender remain } \\
\text { unchanged. }\end{array}$ \\
\hline & $\begin{array}{l}\text { The proportion of older people by age and gender living in } \\
\text { each household type remains constant. }{ }^{1}\end{array}$ \\
\hline $\begin{array}{l}\text { Demand for } \\
\text { services }\end{array}$ & $\begin{array}{l}\text { The proportion of older people receiving informal care, } \\
\text { formal community-care services and residential and nursing } \\
\text { home care remains constant for each sub-group defined by } \\
\text { age, gender and level of dependency. }\end{array}$ \\
\hline \multirow[t]{2}{*}{ Supply of services } & The supply of formal care will adjust to match demand. ${ }^{2}$ \\
\hline & $\begin{array}{l}\text { Demand will be no more constrained by supply in the future } \\
\text { than in the base year. }\end{array}$ \\
\hline $\begin{array}{l}\text { Expenditure and } \\
\text { economic context }\end{array}$ & $\begin{array}{l}\text { The unit-costs of care rise in line with the EPC's assumption }{ }^{3} \\
\text { for the growth in productivity in each country, while GDP } \\
\text { also rises in line with the EPC's assumptions. These assumptions } \\
\text { are country-specific, but based on a common methodology }\end{array}$ \\
\hline
\end{tabular}

Notes: I. This assumption only operates explicitly in the UK model, but it is implicit in the other three models. 2. The models assume that the real rise in wages and other payments for care will ensure that supply is sufficient. Changes to assumptions about unit-costs are made as part of the sensitivity analysis. 3. Details of the assumptions are available in Economic Policy Committee (200I).

older people are expected roughly to double between 2000 and 2050 in Spain and Italy, but that the increases would be rather less in the UK and greater in Germany. The proportion of older people that are dependent is not constant over time, principally because age-specific dependency rates and trends differ by country, and partly as a consequence of different national definitions of dependency.

The projected rates of growth in the volume of services that will be demanded are by and large similar to the projected rises in the numbers of dependent older people. The differentials mainly concern institutional care, which reflects the rise in the probability of receiving institutional services with increasing age for a given level of dependency. Among the four countries, the largest projected rise between 2000 and 2050 in absolute long-term care expenditure would be in Spain, followed by Germany, the United Kingdom and Italy. As a percentage of the gross domestic product (GDP), however, the greatest rise would be in Germany (168\%), followed by Spain (I49\%), Italy (I38\%) and the United Kingdom (II $\%) .{ }^{4}$ Figure I shows the central base-case projected rises in long-term care expenditure as a proportion of GDP. 
292 Adelina Comas-Herrera, Raphael Wittenberg et al.

T А в L Е 3. Central base-case projected increase in the numbers of dependent older people, service recipients and expenditure, 2000 to 2050

\begin{tabular}{|c|c|c|c|c|}
\hline & Germany & Spain & Italy & $\begin{array}{l}\text { United } \\
\text { Kingdom }\end{array}$ \\
\hline & \multicolumn{4}{|c|}{ Percentage increase $2000-2050$} \\
\hline Numbers aged 65 or more years & 64 & 76 & 56 & 67 \\
\hline Numbers aged 85 or more years & I68 & I94 & I68 & I52 \\
\hline Numbers with dependency ${ }^{1}$ & I2I & 102 & 107 & 87 \\
\hline Recipients of informal care only & II9 & IOO & Iog & 72 \\
\hline Recipients of home-based care & II9 & 99 & II9 & 92 \\
\hline Recipients of institutional care & I27 & I 20 & $8 \mathrm{I}$ & III \\
\hline \multirow[t]{2}{*}{ Total expenditure } & 437 & 509 & 378 & $39^{2}$ \\
\hline & \multicolumn{4}{|c|}{ Percentages } \\
\hline $\begin{array}{l}\text { Total expenditure in } 2000 \text { as a } \\
\text { percentage of GDP }\end{array}$ & $\mathrm{I} .24$ & 0.65 & 0.99 & I. 36 \\
\hline $\begin{array}{l}\text { Total expenditure in } 2050 \text { as a } \\
\text { percentage of GDP }\end{array}$ & $3 \cdot 3^{2}$ & I. 62 & 2.36 & 2.89 \\
\hline $\begin{array}{l}\text { Percentage increase in GDP } \\
\text { percentage, 2000-2050 }\end{array}$ & I68 & I 49 & I38 & II 2 \\
\hline
\end{tabular}

Notes I. These figures should be treated with caution as they are based on different measures of dependency; for more detail, see chapter I4 of Comas-Herrera and Wittenberg (2003).

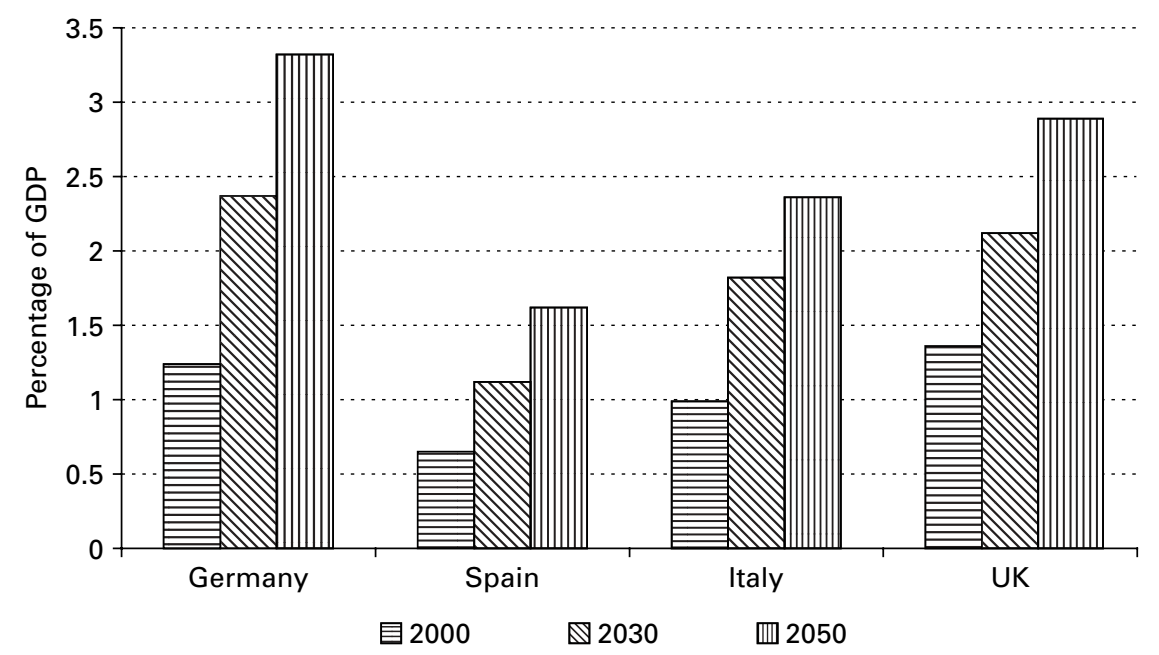

Figure I. Central base-case projected long-term care expenditure as a percentage of GDP.

The sensitivity of the projections to variant assumptions

An important feature of this study has been an investigation of the sensitivity of the projections to changed assumptions about the influential 
factors. This section describes the sensitivity of the projections to the future macroeconomic environment, numbers of older people, dependency rates, and the availability of informal care; their sensitivity to changes in formal care patterns have been reported elsewhere (Pickard et al. 2003).

Projections of future long-term care expenditure require assumptions about the macroeconomic environment, in particular about changes in the real unit-costs of care and economic growth. The models assume that real unitcosts of care will rise in line with productivity, as projected by the European Commission EPC, and that GDP will also rise in line with the EPC projections. ${ }^{5}$ These projections assume that productivity will rise faster than GDP in all four countries, because the projected number of workers is expected to decline. As the difference between productivity and GDP growth varies by country, in order to compare the sensitivity of the models to changes in demography, dependency and care arrangements, a 'comparative base-case' is used for sensitivity analysis that assumes equal real rises in unit-costs and in GDP. The sensitivity analysis on the macroeconomic assumptions was carried out by testing the effect of varying the assumption about the real rise in unit-costs per year by 0.5 percentage points above and below the central case assumption (the central GDP growth assumption was not varied). A rise in unit-costs that is 0.5 percentage points above the EPG productivity assumption represents the scenario in which the earnings of people employed in the delivery of long-term care rise faster than all other earnings. A rise in unit-costs that is 0.5 percentage points less than the EPG assumption has the inverse implication.

Table 4 summarises the results of the sensitivity analysis. Long-term care expenditure as a percentage of GDP is clearly highly sensitive to assumptions about the differential between the assumed growth rate in unit-costs and the assumed growth in GDP. If the real unit-costs of care and GDP grow at similar rates (as in the comparative base case), between 2000 and 2050 the cost of long-term care is projected to roughly double as a proportion of GDP in all four countries. This would be the projected impact of demographic pressures without any allowance for a rising real cost of providing care. If, however, real unit-costs grow more rapidly than GDP (as in the central base case for all countries), the expenditure on long-term care is projected to rise more substantially as a proportion of GDP.

Turning to the assumptions about the future numbers of older people, the sensitivity analysis produced estimates for both the official national population projections and the Eurostat variant population projections. The base case was the Eurostat I999-based central population projections. While the Eurostat central projections for the United Kingdom and Spain 
T A B L E 4. Projected growth in long-term care expenditure, 2000-2050, under different assumptions about real rises in unit-costs of care

\begin{tabular}{|c|c|c|c|c|}
\hline Assumptions and outcomes & Germany & Spain & Italy & $\begin{array}{l}\text { United } \\
\text { Kingdom }\end{array}$ \\
\hline & \multicolumn{4}{|c|}{ Percentages } \\
\hline \multicolumn{5}{|l|}{ Gentral base case } \\
\hline GDP annual growth rate & I.4 & І.8 & I.4 & I.7 \\
\hline Unit-costs, annual growth rate & І.8 & $2 . I$ & І. 8 & I. 8 \\
\hline Increase in GDP percentage, $2000-2050$ & I68.I & I 49.4 & I38.3 & III.9 \\
\hline Percentage of GDP in 2050 & $3 \cdot 32$ & I. 62 & 2.36 & 2.89 \\
\hline \multicolumn{5}{|c|}{ Unit-costs rise $0.5 \%$ faster than EPG productivity assumptions } \\
\hline GDP annual growth rate & I. 4 & I. 8 & I.4 & I.7 \\
\hline Unit-costs, annual growth rate & 2.3 & 2.6 & 2.3 & 2.3 \\
\hline Increase in GDP percentage, $2000-2050$ & 242.5 & $2 \mathrm{I} 8.4$ & 204.5 & I70. 6 \\
\hline Percentage of GDP in 2050 & 4.24 & 2.06 & 3.02 & 3.69 \\
\hline \multicolumn{5}{|c|}{ Unit-costs rise $0.5 \%$ slower than EPC productivity assumptions } \\
\hline GDP annual growth rate & I.4 & I.8 & I.4 & I.7 \\
\hline Unit-costs, annual growth rate & I. 3 & I. 6 & I. 3 & I. 3 \\
\hline Increase in GDP percentage, $2000-2050$ & Iog. 6 & 95.I & 86.3 & 65.6 \\
\hline Percentage of GDP in $205^{\circ}$ & 2.59 & I. 26 & ז.86 & 2.26 \\
\hline \multicolumn{5}{|l|}{ Equal growth in both GDP and unit-costs ${ }^{1}$} \\
\hline Increase in GDP percentage, $2000-2050$ & $\mathrm{I} 20.2$ & II 5.3 & 95.8 & IOI.7 \\
\hline Percentage of GDP in 2050 & 2.72 & I.39 & I.94 & 2.75 \\
\hline
\end{tabular}

Notes: I. Comparative base case for use in sensitivity analysis.

are similar to the national official projections, they differ substantially for Germany and even more for Italy. The Eurostat high variant population projection assumes high migration rates, high fertility rates and high average life expectancy, while the low variant assumes low migration, fertility and life expectancy. The variant projections differ greatly, and have a considerable impact on the projected number of dependent people and on long-term care expenditure (Table 5). In Italy, in particular, using the national official population projections instead of the Eurostat projections has a major impact on the model's projection of long-term care expenditure.

The level of dependency is a crucial determinant of demand for long-term care for it, rather than age, determines need. There is a great uncertainty about the future rates of dependency, especially as average life expectancy increases. The available evidence presents a complex pattern of recent trends in dependency rates in different countries (Robine, Romieu and Michel 2003). A review by the Organisation for Economic Cooperation and Development (OECD) found that the trends in the prevalence of dependency varied substantially among its member countries (Jacobzone, Cambois and Robine 2000). More recently, the International Network on Health 
T A в L E 5. Projected increases in the numbers of people with dependency and long-term care expenditure, 2000-2050, by variant population projections

Germany

Comparative base case (central Eurostat projection)

Growth in number aged 65 or more years

Growth in number aged 85 or more years

Increase in GDP percentage, 2000-2050

Percentage of GDP in $205^{\circ}$

High variant Eurostat population projections

Growth in number aged 65 or more years

Growth in number aged 85 or more years

Increase in GDP percentage, 2000-2050

Percentage of GDP in $205^{\circ}$

Low variant Eurostat population projections

Growth in number aged 65 or more years

Growth in number aged 85 or more years

Increase in GDP percentage, 2000-2050

Percentage of GDP in $205^{\circ}$

National official population projections

Growth in number aged 65 or more years

Growth in number aged 85 or more years

Increase in GDP percentage, 2000-2050

Percentage of GDP in $205^{\circ}$

$\begin{array}{cc}64 & 76 \\ \text { I68 } & \text { I94 } \\ \text { I20 } & \text { II5 } \\ 2.72 & \text { I.39 }\end{array}$

\section{4}

22 I

I6I

3.23

42
97
76
2.18

39
I 33
I09
2.66

71
I 80
IIO
I. 37

Spain

Italy

Kingdom
Percentages

$\begin{array}{ccc}\text { I0o } & 78 & 93 \\ 3 \mathrm{I} 7 & 274 & 266 \\ \text { I6I } & \mathrm{I} 79 & \mathrm{I} 54 \\ \text { I.69 } & 2.27 & 3.46\end{array}$

$\begin{array}{ccc}55 & 39 & 47 \\ 90 & \text { IOI } & 83 \\ 74 & \text { IO9 } & 67 \\ \text { I.I3 } & \text { I.70 } & 2.27\end{array}$

67

$\mathrm{I} 52$

IO2

2.75 $3 \cdot 46$

$7 \mathrm{I}$
I 75
I06
$\quad 2.86$

Expectancy and the Disability Process, REVES, ${ }^{6}$ has calculated harmonised, disability-free, average life expectancies for many developed countries. These indicate that severe disability (dependency in ADL) has been declining in the United Kingdom, Finland, Switzerland and France, but has been stable in the United States and The Netherlands, and increasing substantially in Australia and possibly Japan (Robine and Michel 2004: 593). The review concluded that the available evidence does not warrant a single forecast for the expansion or compression (over years of life) of morbidity, but characterised the trend as a series of transitional stages that are specific to countries and different periods.

The base-case models assume that age and gender-specific dependency rates do not change over time. The figures in Table 6 show the impact on the projected numbers of dependent older people and future long-term care expenditure of alternative assumptions about the link between improved life expectancy and delayed dependency. In the first scenario, dependency rates are delayed by the same number of years as life expectancy at birth is assumed to increase by the Eurostat population projections $;^{7}$ in the alternative scenario, dependency rates are delayed by half the number of years by which life expectancy at birth increases. The impact of the 
T A B L E 6. Projected increase in the numbers of people with dependency and long-term care expenditure, 2000-2050, under different assumptions about trends in dependency

\begin{tabular}{|c|c|c|c|c|}
\hline Assumption and outcomes & Germany & Spain & Italy & $\begin{array}{l}\text { United } \\
\text { Kingdom }\end{array}$ \\
\hline & \multicolumn{4}{|c|}{ Percentages } \\
\hline \multicolumn{5}{|c|}{ Gomparative base case (constant dependency rates) } \\
\hline Growth in number with dependency & I2I & 102 & 107 & 87 \\
\hline Increase in GDP percentage, $2000-2050$ & 120 & II5 & 96 & I02 \\
\hline Percentage of GDP in $205^{\circ}$ & 2.72 & I.39 & I.94 & 2.75 \\
\hline \multicolumn{5}{|c|}{ A one year rise in average life expectancy delays dependency by one year } \\
\hline Growth in number with dependency & 34 & $5^{6}$ & $-I$ & 35 \\
\hline Increase in GDP percentage, $2000-2050$ & 29 & 64 & 27 & 45 \\
\hline Percentage of GDP in 2050 & I. 58 & I.06 & I. 26 & I. 98 \\
\hline \multicolumn{5}{|c|}{ A one year rise in life expectancy delays dependency by 0.5 years } \\
\hline Growth in number with dependency & 73 & 79 & $4 \mathrm{I}$ & 6I \\
\hline Increase in GDP percentage, $2000-2050$ & 72 & 90 & 54 & 73 \\
\hline Percentage of GDP in $205^{\circ}$ & $2 . \mathrm{II}$ & $\mathrm{I} .23$ & I.53 & 2.36 \\
\hline
\end{tabular}

alternative dependency assumptions depends on the expected increase in average life expectancy at birth in each country. The increases projected by Eurostat between 2000 and 2050 are, for Italy, 7.28 years for men and 4.94 years for women, and for Spain, 5.50 years for men and 3.30 years for women; the projections for Germany and the United Kingdom lie inbetween. The alternative scenarios have greater impact in Germany and Italy than in Spain or the UK.

We now turn to the sensitivity of the models to the assumptions about informal care, the most important source of support for dependent older people in all four countries. Several social trends suggest that over the long term, informal care is likely to decline in developed countries (OECD I996). There is evidence of a downward trend in older people's co-residence with their children (Grundy 1995), of an increase in older people living alone (Alders and Manting 2004; Evandrou and Falkingham 200o), of declining female care-giving potential (Salvage 1995), and of rising female labour-force paticipation rates (Kyi and Charlier 200I; Spiess and Schneider 200I). A reduction in informal care would have a major impact on the demand for formal care, and its trend will have an important influence on future long-term care expenditure.

The definition of informal care used in the models varied among the four countries, but in all referred to dependent older people who relied exclusively on informal care, and therefore excluded those who used formal services as well as informal care (Pickard 2003 $b$ ). Given that detailed data on informal care were unavailable for some of the countries, this definition 
T A в L E 7. Projected increase in numbers of older people receiving informal and formal care and increase in long-term care expenditure, 2000-2050, under different assumptions about informal care

\begin{tabular}{|c|c|c|c|c|}
\hline Assumptions and outcomes & Germany & Spain & Italy & $\begin{array}{l}\text { United } \\
\text { Kingdom }\end{array}$ \\
\hline & \multicolumn{4}{|c|}{ Percentages } \\
\hline \multicolumn{5}{|l|}{ Comparative base case } \\
\hline Number receiving informal care only & II9 & IOO & IO9 & 72 \\
\hline Number receiving home-based care & II9 & 99 & II 9 & 92 \\
\hline Number receiving institutional care & 127 & 120 & $8 \mathrm{I}$ & I I I \\
\hline Increase in GDP percentage, $2000^{-} 5^{\circ}$ & $\mathrm{I} 2 \mathrm{O}$ & II 5 & $9^{6}$ & IO2 \\
\hline Percentage of GDP in $205^{\circ}$ & 2.72 & I.39 & I.94 & 2.75 \\
\hline \multicolumn{5}{|c|}{$0.5 \%$ decrease in number receiving informal care, with increased institutionalisation } \\
\hline Number receiving informal care only & 70 & 82 & 63 & 6 o \\
\hline Number receiving home-based care & II9 & 99 & I I9 & 92 \\
\hline Number receiving institutional care & I95 & 260 & I54 & I47 \\
\hline Increase in GDP percentage, $2000^{-} 5^{\circ}$ & $\mathrm{I} 48$ & 236 & $15^{8}$ & $\mathrm{I} 2 \mathrm{O}$ \\
\hline Percentage of GDP in $205^{\circ}$ & 3.07 & 2.18 & 2.55 & 2.99 \\
\hline \multicolumn{5}{|c|}{$\begin{array}{l}0.5 \% \text { decrease in number receiving informal care only, with increased home-base } \\
\text { formal care }\end{array}$} \\
\hline Number receiving informal care only & 70 & 82 & 63 & 60 \\
\hline Number receiving home-based care & 226 & I86 & I6I & IOI \\
\hline Number receiving institutional care & I 27 & $\mathrm{I} 20$ & 8I & III \\
\hline Increase in GDP percentage, $2000^{-} 5^{\circ}$ & I 27 & I34 & IO9 & I07 \\
\hline Percentage of GDP in $205^{\circ}$ & $2.8 \mathrm{I}$ & I. $5^{2}$ & 2.07 & 2.82 \\
\hline \multicolumn{5}{|c|}{$\begin{array}{l}\text { I\% decrease in number receiving informal care, increased home-based care an } \\
\text { institutionalisation }\end{array}$} \\
\hline Number receiving informal care only & $3^{2}$ & 67 & 27 & $5^{\mathrm{I}}$ \\
\hline Number receiving home-based care & $2 \mathrm{I} 5$ & I76 & I57 & IOO \\
\hline Number receiving institutional care & I87 & 245 & I46 & I 43 \\
\hline Increase in GDP percentage, $2000^{-} 5^{\circ}$ & I62 & 240 & I63 & $\mathrm{I} 22$ \\
\hline Percentage of GDP in $205^{\circ}$ & 3.24 & 2.20 & 2.60 & 3.03 \\
\hline
\end{tabular}

was adopted to maximise comparability between the models. Three scenarios were developed to test the sensitivity of the models to a decline in informal care. Two assume a decline of 0.5 per cent a year in the proportion of dependent older people who receive informal care; they are differentiated by a second alternative assumption, that those no longer receiving informal care either move into institutions or receive 'an average package' of home-care. The third scenario assumes a decline of one per cent each year in the proportion of dependent older people who receive informal care, with one-half moving into institutions and one-half receiving home-care.

The results of the scenarios suggest that, in all four countries, the impact of a decline in informal care would depend on the type of formal care that is provided in its place (Table 7). An increase of institutional care would 
increase expenditure much more than an increase of home-based care. A uniform proportionate decline in informal care would, however, increase the demand for formal care more in some countries than others. The impact would be least in the UK and greatest in Spain, simply because Spain currently relies far more heavily on informal care. The study also explored the effects of the level of informal care in Spain declining to the current UK level and found, not surprisingly, that the impact on the demand for formal care in Spain would be considerable (Pickard 2003b). Nonetheless, the impact on long-term care expenditure would depend very much on the type of formal care that is substituted.

\section{Conclusions}

Key results

The proportion of GDP that would be spent on long-term care is projected to more than double between 2000 and 2050 in each country under the central projection, which uses the Eurostat population projections, and assumes rises in care costs and GDP that are in line with the European Commission EPC assumptions about productivity and economic growth. The central projection assumes that the prevalence rates of age-specific dependency remain constant.

The sensitivity analysis showed that the projected future demand for long-term care services for older people is sensitive to assumptions about the future number of older people and future dependency rates, and that future expenditure on long-term care for older people is highly sensitive to the real unit-costs of providing services, and to the availability of informal care. Analyses reported elsewhere have shown also that the demand for long-term care and associated expenditure is sensitive to assumptions about the patterns of service provision (Pickard et al. 2003).

The assumptions that have been used are plausible but clearly do not exhaust the possibilities. It is emphasised that the projections should not be regarded as forecasts, and that the expenditure projections would not constitute the total costs of long-term care to society. That estimation would require inclusion of both the costs to public agencies and service users of a wider range of services and the opportunity costs of informal care. It should also be stressed that no allowance has been made here for changes in public expectations about the quality, range or level of care.

The base-case models project that the proportion of GDP required to fund long-term care services for older people will need to rise substantially between 2000 and 2050. This finding suggests that improvements in efficiency will be important, to restrain the rise in unit-costs. It needs to be 
recognised, however, that the scope for rises in the efficiency of long-term care services are limited because they are very labour intensive. It also suggests that raising the cost-effectiveness of long-term care will be important. This may require closer matching of services to needs, not only to increase the benefits relative to expenditure but also to improve the outcomes for service users and their families. Similarly, the potential impact of decreases in informal care suggests that, particularly in Spain and Italy, it will be important to provide support for informal carers. As female labour-market participation rates rise, such support will be especially important to help carers combine paid-work and informal care. Finally, the findings suggest that policy-makers need to plan for uncertainty in the demand for long-term care for dependent older people; future mortality rates, dependency rates, the availability of informal care and rises in unit-care costs are all inevitably uncertain, and all will have substantial impacts on the demand for long-term care and the associated public expenditure.

\section{Acknowledgements}

This study was partly funded by the European Commission Employment and Social Affairs Directorate General (grant VS/2001/0272). The authors are grateful to Martin Knapp, Elias Mossialos and Bleddyn Davies for their support throughout the project.

\section{NOTES}

I Throughout this article, 'dependency' is a short form for 'functional dependency' defined with reference to the ability to perform the activities of daily living (ADLs) and/or instrumental activities of daily living (IADLs).

2 The Spanish model has since been used for a generational-accounting case study (Costa and Patxot 2004).

3 They do not include, however, the opportunity costs of providing informal care.

4 The difference between absolute and relative expenditure in long-term care is determined by the difference between the projected rate of growth of the real unit-costs of care and the projected annual growth in GDP ( $0.4 \%$ for Germany and Italy, $0.3 \%$ for Spain, and 0.I \% for the UK). The differences between the two figures are based on assumptions used in the EPG report (200I) about the rates of decline in the working population in a country.

5 This assumes that the costs of care will rise in line with wages, and that wages will rise in line with productivity.

6 More information is available online at http://www.prw.le.ac.uk/reves/

7 The base-year dependency rate for those aged, for example, 70 years, is applied under the first scenario to those aged 72 years in the year in which expected average life expectancy was two years higher than base-year average life expectancy. Under the second scenario, it is applied to those aged 7I years. 


\section{References}

Alders, M. and Manting, D. 2004. Household scenarios for the European Union, I995-2025. In Hullen, G. (ed.), Living Arrangements and Households: Methods and Results of Demographic Projections. Materialen zur Bevölkerungswissenschaft [Materials of Demography], Volume ıog, Bundesinstitut für Bevölkerungsforschung [Federal Institute for Demographic Research], Wiesbaden, Germany, 7I-95.

Comas-Herrera, A. and Wittenberg, R. (eds) 2003. European Study of Long-Term Care Expenditure. Report to the Employment and Social Affairs Directorate General (DG) of the European Commission, PSSRU Discussion Paper I840, London School of Economics, London. Available online at http://europa.eu.int/comm/employment_social/soc-prot/healthcare/ltc_study_en.pdf

Comas-Herrera, A., Pickard, L., Wittenberg, R., Darton, R. and Davies, B. 2003. Future Demand for Long-Term Care 200I to 203I: Projections of Demand for Older People in England. PSSRU Discussion Paper 1980, London School of Economics, London.

Comas-Herrera, A., Wittenberg, R. and Pickard, L. 2004. Long-term care for older people in the United Kingdom: structure and challenges. In Knapp, M., Challis, D., Fernández, J. L. and Netten, A. (eds), Towards Equitable and Efficient Social Care: Festschrift for Bleddyn Davies. Ashgate, Aldershot, Hampshire, I7-33.

Costa-Font, J. and Patxot, C. 2003. Long-term care for older people in Spain. In ComasHerrera, A. and Wittenberg, R. (eds), European Study of Long-Term Care Expenditure. Report to the Employment and Social Affairs DG of the European Commission, PSSRU Discussion Paper I840, London School of Economics, London, 43-58.

Costa-Font, J. and Patxot, C. 2004. The intergenerational impact of long-term care financing alternatives in Spain. Geneva Papers on Risk and Insurance, 29, 599-620.

Costa-Font, J. and Patxot, C. 2005. The design of the long-term care system in Spain: policy and financial constraints. Social Policy and Society, 4, I I-20.

Economic Policy Committee 200I. Budgetary Challenges Posed by Ageing Populations: The Impact on Public Spending, Health and Long-Term Care for the Elderly and Possible Indicators of the LongTerm Sustainability on Public Finances. Directorate General for Economic and Financial Affairs, European Commission, Brussels.

Economic Policy Committee 2003. The Impact of Ageing Population on Public Finances: Overview of Analysis Carried Out at EU Level and Proposals for a Future Work Programme. Directorate General for Economic and Financial Affairs, European Commission, Brussels.

Evandrou, M. and Falkingham, J. 200o. Looking back to look forward: lessons from four birth cohorts for ageing in the 2ist century. Population Trends, 99, 27-36.

Glendinning, C., Davies, B., Pickard, L. and Comas-Herrera, A. 2004. Funding Long-Term Care for Older People: Lessons from Other Countries. Joseph Rowntree Foundation, York.

Gori, C., Di Maio, A. and Pozzi, A. 2003. Long-term care for older people in Italy. In Comas-Herrera, A. and Wittenberg, R. (eds), European Study of Long-Term Care Expenditure. Report to the Employment and Social Affairs DG of the European Commission, PSSRU Discussion Paper 1840, London School of Economics, London, 59-76.

Grundy, E. 1995. Demographic influences on the future of family care. In Allen, I. and Perkins, E. (eds), The Future of Family Care for Older People. Her Majesty's Stationery Office, London, I-I7.

Jacobzone, S., Cambois, E. and Robine, J. M. 2000. Is the Health of Older Persons in the OECD Countries Improving Fast Enough to Compensate for Population Ageing? Economic Study 30 2000/I, Organisation for Economic Cooperation and Development, Paris.

Kyi, G. and Charlier, H. 2001. Employment Rates in Europe, 200o. Statistics in Focus: Population and Social Conditions. Theme 3-8/200I, Office for Official Publications of the European Communities, Brussels. 
Organisation for Economic Cooperation and Development (OECD) I996. Caring for Frail Elderly People: Policies in Evolution. Social Policy Study ig, OECD, Paris.

Pickard, L. 200za. Trends in and projections for formal care. In Comas-Herrera, A. and Wittenberg, R. (eds), European Study of Long-Term Care Expenditure. Report to the Employment and Social Affairs DG of the European Commission, PSSRU Discussion Paper 1840, London School of Economics, London, 206-29.

Pickard, L. 2003b. Trends in and projections for informal care. In Comas-Herrera, A. and Wittenberg, R. (eds), European Study of Long-Term Care Expenditure. Report to the Employment and Social Affairs DG of the European Commission, PSSRU Discussion Paper I840, London School of Economics, London, I80-05.

Pickard, L., Comas-Herrera, A., Costa-Font, J., Gori, C., Di Maio, A., Rothgang, H. and Wittenberg, R. 2003. Modelling an Entitlement to Long-Term Care in Europe: Projections for LongTerm Care Expenditure to 2050. Paper presented at the European Sociological Association Conference, Murcia, Spain, 23-26 September. Available online at http://www.um.es/ ESA/papers/Rni_26.pdf

Robine, J. M., Romieu, I. and Michel, J. P. 2003. Trends in health expectancies. In Robine, J. M., Jagger, C., Mathers, C. D., Crimmins, E. M. and Suzman R. M. (eds), Determining Health Expectancies. Wiley, Chichester, Sussex, 75-гог.

Robine, J. M. and Michel, J. P. 2004. Review article: looking forward to a general theory on population aging. Fournal of Gerontology: Medical Sciences, 59A, 6, 590-7.

Rothgang, H. 1997. Ziele und Wirkungen der Pflegeversicherung. Eine ökonomische Analyse [Goals and Effects of the Long-Term Care Insurance: An Economic Analysis]. Schriften des Zentrum für Sozialpolitik 7 [Centre for Social Policy Research Studies 7], Campus, Frankfurt, Gemany.

Rothgang, H. 2002a. Finanzwirtschaftliche und strukturelle Entwicklungen in der Pflegeversicherung bis 2040 und mögliche alternative Konzepte [Fiscal and structural developments of public long-term care insurance until 2040 and alternative concepts]. In Enquete Kommission Demographischer Wandel des Deutschen Bundestags [Demographic Change Commission of the German Federal Parliament], Herausforderungen unser älter werdenden Gesellschaft an den einzelnen und die Politik [Challenges of an Ageing Population for Everyone and for Policy]. R. V. Decker, Heidelberg, Germany, I-254.

Rothgang, H. $2002 b$. Projections on public long-term care insurance financing. In Conrad, H. and Lützeler, R. (eds), Aging and Social Policy: A German-fapanese Comparison. Iudicum, Munich, Germany, 25I-73.

Rothgang, H. 2003. Long-term care for older people in Germany. In Comas-Herrera, A. and Wittenberg, R. (eds), European Study of Long-Term Care Expenditure. Report to the Employment and Social Affairs DG of the European Commission, PSSRU Discussion Paper 1840. London School of Economics, London, 24-42.

Rothgang, H and Comas-Herrera, A. 2003. Dependency rates and health expectancy. In Comas-Herrera, A. and Wittenberg, R. (eds), European Study of Long-Term Care Expenditure. Report to the Employment and Social Affairs DG of the European Commission, PSSRU Discussion Paper 1840. London School of Economics, London. 159-78.

Salvage, A. 1995. Who Will Care? Future Prospects for Family Care of Older People in the European Union. European Foundation for the Improvement of Living and Working Conditions, Dublin.

Schneider, U. I999. Germany's social long-term care insurance: design, implementation and evaluation. International Social Security Review, 52, 31-74.

Spiess, C and Schneider, U. 200I. Midlife Caregiving and Employment: An Analysis of Work Hours and Informal Care Hours for Female Employees in the EU. Paper presented to the 2nd Research Conference of the International Research Network on Elder Care, Hanover, Germany, 8 February. 
Ungerson, C. 2004. Whose empowerment and independence? A cross-national perspective on 'cash for care' shemes. Ageing \& Society, 24, 2, I89-212.

Wittenberg, R., Pickard, L., Comas-Herrera, A., Davies, B. and Darton, R. 1998. Demand for Long-Term Care: Projections of Long-Term Care Finance for Elderly People. Personal Social Services Research Unit, University of Kent, Canterbury, Kent.

Wittenberg, R., Pickard, L., Comas-Herrera, A., Davies, B. and Darton, R. 200r. Demand for long-term care older people in England to 2031. Health Statistics Quarterly, I 2, 5-17.

Address for correspondence:

Accepted I9 July 2005

Adelina Comas-Herrera, Personal Social Services Research Unit, LSE Health and Social Care, London School of Economics and Political Science, Houghton Street, London $\mathrm{WC}_{2} \mathrm{AE}{ }_{2} \mathrm{AE}$, United Kingdom.

e-mail: a.comas@lse.ac.uk 